\title{
Urgences
}

\section{R en bannière}

\section{Anne Bernier}

Numéro 13, mars 1986

\section{Éclats d'atelier}

URI : https://id.erudit.org/iderudit/025202ar

DOI : https://doi.org/10.7202/025202ar

Aller au sommaire du numéro

\section{Éditeur(s)}

Urgences

\section{ISSN}

0226-9554 (imprimé)

1927-3924 (numérique)

Découvrir la revue

Citer ce document

Bernier, A. (1986). R en bannière. Urgences, (13), 21-21.

https://doi.org/10.7202/025202ar

Ce document est protégé par la loi sur le droit d'auteur. L'utilisation des services d'Érudit (y compris la reproduction) est assujettie à sa politique d'utilisation que vous pouvez consulter en ligne.

https://apropos.erudit.org/fr/usagers/politique-dutilisation/ 


\section{R EN BANNIÈRE Anne Bernier}

À l'issue toute nue, l'onaniste éberlué a nié; devant l'anatomie qui se berce de curieuse manière, il analyse et libère de leur nid, étouffés, d'éblouissants fantasmes de ces années où il était pubère. $\mathrm{Ni}$ étoiles, ni musique, ni davantage de canapé; aberrant constat, le maniaque émasculé lui avait-il déjà ressemblé? Nommer l'anonyme, puisque l'imberbe avait déjà manié le rasoir, il s'y était sûrement mouillé... Et l'anarchie dépendante des berceaux, en était-il le jardinier? Enfin, la panne, le sexe en berne et le septième ciel au panier! N'empêche que rien n'est banal; le grand Robert en tête, l'énigme éclabousse la jolie rousse et l'anormale à béret dont la canicule est plutôt intérieure souffre d'anémie. Pour atteindre le bercail, il lui faut la manière et le verbe. Encore hier, l'analphabète bergère comptait quelques araignées à son plafond. Rrrrrr, l'animal de Robert sera-t-il épargné? Divine anémone engloutie, rêvant aujourd'hui des Bermudes et demain de Nicolas, échouée doucement sous l'ambre de sa chevelure. Le vaisseau s'anime tout à coup, cherche les berges aux fanions évidents, mais sans succès... Et en annexe elle revient à ses moutons qui se bercent mais qui jamais ne sautent, en Irlande évidemment... Notre évanescente a la berlue, le manifeste, éblouie. Oh, manoeuvre douteuse, le cher Bébert n'y tient plus, hélas. Rage, panique, la bergère, ainsi manipulée, disparaît. Damnation, le grand Robert se meurt en hurlant à l'orgasme dernier! 